\section{REGION}

Volume 8, Number 2, 2021, 187-199

DOI: $10.18335 /$ region.v8i2.364
The Journal of ERSA

Powered by WU

journal homepage: region.ersa.org ISSN: $2409-5370$

\title{
Urban tourism and Covid-19 in Poland
}

\author{
Karolina Józefowicz ${ }^{1}$ \\ ${ }^{1}$ Poznań University of Life Sciences, Poznań, Poland \\ Received: 11 April 2021/Accepted: 17 November 2021
}

\begin{abstract}
World Tourism Organisation estimates an $80 \%$ drop in tourist arrivals by the end of 2020. The Polish tourism industry is also dramatically affected by the ongoing pandemic, with a 30\% drop in the number of tourists in July 2020 compared to July 2019. The global lockdown has limited the functioning of the tourism sector, therefore domestic tourism, including urban tourism, may rise in importance. Domestic urban tourism can become a useful response to the growing resilience of the tourism industry, for example in the context of reducing dependence between the tourism industry and mobility which favours the spread of coronavirus. The potential of urban tourism in Poland is clearly visible (in 2019, it was three times higher than rural tourism in terms of overnight stays provided). However, the COVID-19 pandemic is not conducive to urban tourism in Poland, for instance, because infections are much more frequent in cities than in rural areas. The aim of the research, in addition to checking destinations of Poles in the context of urban tourism in the era of the pandemic, was to learn about the behaviour of tourists during their holiday trips. To achieve the aim of the paper, the study was conducted from 16 to 31 August 2020, using CAWI survey method, among people who visited Polish cities starting from May 2020 through the end of August 2020 (following the partial lifting of restrictions). The research indicated, despite the threat, the popularity of the largest tourist destinations in Poland. It also indicated that the behaviour and decisions of tourists were not different from those before the pandemic.
\end{abstract}

\section{Introduction}

The ongoing COVID-19 pandemic is causing great havoc to the world economy. A broad range of consequences of the pandemic is also experienced by the tourism sector, which according to Fletcher et al. (2020) is considered to be the world's largest industry, generating $10 \%$ of global GDP (is closely linked to socio-economic progress) (Anand, Kim 2021, Kyrylov et al. 2020). For the European Union, tourism is the fourth largest export category, and for countries such as France, Spain and Italy it is one of the main economic segments (Komisja Europejska 2020). According to the World Tourism Organization (2020), the global tourist blockade may cause the estimated number of international tourist arrivals at the end of 2020 to be nearly $60-80 \%$ lower than last year. In the research carried out by Richards, Morrill (2020), almost all of the analyzed companies from the tourism industry have already experienced a decline in demand and expect this trend to last another year, which is tantamount to a deterioration of their business prospects ${ }^{1}$.

\footnotetext{
${ }^{1}$ The study was conducted in the period from 3-9 March 2020, among the respondents who are representatives of the tourism industry and who have connections with WYSE Travel. The surveys were conducted in 73 countries and 421 questionnaires were retained for analysis (Richards, Morrill 2020,
} 
Current statistics show that in Poland, in May 2020, the number of tourists decreased by nearly $90 \%$ compared to May 2019, in June 2020 by more than $60 \%$ compared to the previous year, and in July 2020, compared to the same month last year, by more than $30 \%$, while the number of foreign tourists was lower by nearly $70 \%$ (Główny Urząd Statystyczny 2020b,c).

The COVID-19 pandemic is not the first crisis of the tourism sector (SARS epidemic in early 2000, economic downturn in 2009, terrorist attack of 11 September 2001, MERS in 2012), but the first of such a wide scale that the industry is experiencing (Richards, Morrill 2020, Jamal, Budke 2020, Gössling et al. 2020, Richards 2020). The SARS outbreak caused tourists to avoid areas considered to be at risk (Napierała et al. 2020), and the same is true for geopolitical situations that result in a reduction in available tourism infrastructure (Więckowski, Saarinen 2019).

Global changes, such as increase in population and its mobility, population concentration, urbanisation trends or the development of global transport networks are the causes of the growing threat of a pandemic and the spread of infectious diseases (tourism also indirectly contributes to the development of pandemic) (Labonte et al. 2011). In order to reduce the number of infections, restrictions were introduced that directly affected tourism: suspension of domestic and international flights, cancellation of events (Napierała et al. 2020) or limiting the number of hotel stays or closing them completely for a certain period of time. According to Orîndaru et al. (2021), hygiene and health conditions at the destination have become important for tourists' travel decisions. This has forced hotel companies to change their operating strategies (Rodríguez-Anton, del Mar Alonso-Almeida 2020).

The COVID-19 crisis, according to Gössling et al. (2020), provides an opportunity to take a slightly more critical look at the tourism industry and, at the same time, to search for bigger benefits, focusing on sustainable development issues, among other things, which means rejecting the classical "growth" which is based on bringing profits only to the selective sectors (e.g. airlines, hotels; more extensively on this topic Polukhina et al. 2021, Lerario, Di Turi 2018, Grah et al. 2020). Covid-19 also prompted discussion of sustainable tourism (Lama, Rai 2021, Vărzaru et al. 2021, Purcell et al. 2021) defined as minimizing the negative and maximizing the positive social, economic, and environmental impacts of tourism (Więckowski 2021).

The coronavirus has transformed part of social and economic life, reducing transport and making videoconferences more popular. Both provide a good solution both in education and office work because they allow avoiding unnecessary travel, thus reducing mobility. The observed changes can represent the beginning of the tourism system transformation and thus the process of building resilience, which is currently at a marginal level. The current changes are a sort of precursor for the modifications that will take place in the future. The motivation for their consolidation and development should be based on the fact that in the era of globalization and ongoing transformations, even assuming that the COVID-19 pandemic will end (or return to normality will be allowed), it should be noted that this will not be the last infectious disease threatening society and the entire economy.

\section{Tourism of a place against the pandemic}

Cities have always been tourist destinations, from those of a cognitive (cultural-historical) (Lerario, Di Turi 2018, Barrera-Fernandez et al. 2016) nature to more modern forms of individual tourism, such as business tourism (e.g. conferences, exhibitions) ${ }^{2}$. As a result of the transformations in the area of creating new forms of tourism, a new concept appeared, i.e. urban tourism, which has become an element of the socio-economic development of the city (Żabińska 2013) and one of the fastest-growing forms of tourism in the world (Królikowska-Tomczak, Machnik 2019). Urban tourism is one of the key factors in the development of European cities (Popescu, Corbos 2010).

WYSE Travel Confederation 2020).

${ }^{2}$ This study focuses on cognitive tourism trips, or leisure tourism. 
The majority of foreign tourists coming to Poland, but also the domestic tourist trips of Poles, are aimed at cities (Sala 2012). In 2019, the number of nights spent by tourists in cities was three times higher than the number of nights spent in the countryside (Główny Urząd Statystyczny 2020a). Urban agglomerations are the leading destination for urban tourism. Moreover, among the most visited cities in the world there are examples where, per year, the number of tourists exceeds the number of inhabitants (e.g. Venice) (Królikowska-Tomczak, Machnik 2019). The COVID-19 pandemic, therefore, affects urban tourism in a special way because most cases of infections (Roman et al. 2020) and deaths are accumulated in cities $^{3}$, which negatively affects the city's attractiveness score (Szołtysek, Otręba 2020).

However, due to the restrictions introduced, but also due to people's fear of foreign trips, in the short term, domestic trips will prevail (Komisja Europejska 2020). Therefore, domestic tourism is particularly relevant and an opportunity to revive the tourism industry in the era of pandemic. It can also be said that the situation has stimulated a creative approach to tourism by taking advantage of the diversity, culture and nature offered by the home country. According to a survey commissioned by the Polish Tourist Organisation (2020) in June 2020 on Poles' holiday plans, 64\% of the respondents indicated that the pandemic affected their travel plans. Moreover, among the respondents who declared that they are not planning any vacations in 2020 , for nearly $80 \%$ the reason is the COVID-19 pandemic. Among those who intended to go on vacation in summer 2020, $82 \%$ of Poles plan to take advantage of domestic tourism.

The ongoing pandemic gives a possibility to analyze tourist's behaviour during the epidemic, thus finding opportunities to maintain the future sustainability of the tourism industry (Wachyuni, Kusumaningrum 2020). Before the pandemic, the choice of holiday destination was determined by specific features including age, marital status, income, and education. An additional group of factors were the features that can be attributed to the place of departure (tourist attractions, services, facilities) (Wachyuni, Kusumaningrum 2020), i.e. tourist resources that the place offers. That group of factors should also include determinants related to the availability of a given area, transport connections, or factors including, among others, security or political stability issues. It can therefore be concluded, as Keller (2020) rightly points out that tourism is a "good weather sector". A certain breakdown in cross-sectoral characteristics, especially in the areas related to epidemics or political issues, disturbs the tourism industry causing crises. As a result, the factors related to the destination's tourist resources are somewhat secondary in nature. The pandemic has tourists face a limited choice, combined with their own concerns about safety during the rest time. Therefore, tourists aware of the limitations are looking for holiday attractions that are within their reach.There are many benefits of such solutions, from support of the national tourism industry to more indirect ones, connected with education, discovering local attractions or culture, normally lost to foreign vacations.

\section{Polish tourist voucher as support for the weakened tourism industry}

One of the possibilities to support the reviving tourism industry is to subsidize tourism consumption (Yang et al. 2020). Such a solution was applied, among others, in China after the global economic crisis. In Poland, the collapse of the tourism industry, confirmed by the statistics and forecasts conducted in the country, has led to the government to introduce a tool that will indirectly support the Polish tourism sector, weakened by the COVID-19 pandemic. This tool is the Polish Tourist Voucher, which was introduced on 1 August 2020. It is a form of support that can be used by Polish families with children to pay for a stay in a hotel, an agritourism farm, a sports camp or a colony, as well as to finance a tourist event organized by a tourist entrepreneur or public benefit organization in the country ${ }^{4}$. This kind of element of subsidizing tourism consumption in Poland, although mainly supposed to benefit the tourism industry, also indirectly supports Polish families during the crisis caused by the pandemic. As an incentive for domestic tourism, it can also contribute to the popularization of urban tourism.

\footnotetext{
${ }^{3}$ According to estimates, 90\% of the reported COVID-19 cases concern cities (UN Habitat 2020).

${ }^{4}$ https://www.gov.pl/web/rozwoj/bonturystyczny (Date of access: 14.09.2020).
} 


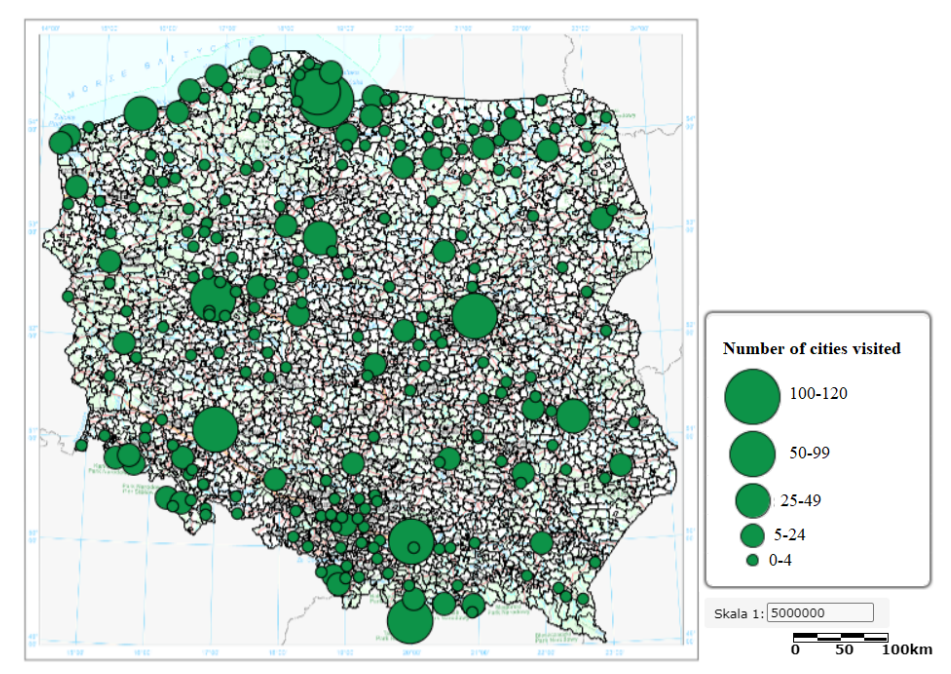

Source: Own study based on surveys, $n=543$.

Figure 1: Number of tourists surveyed by urban destination in Poland

\section{Material and test methods}

In the Holiday Plans of Poles report, half of Polish tourists declared that they will realize their holiday trips in the second half of July and the first half of August (Polish Tourist Organisation 2020). Taking into account the information contained in the report, CAWI surveys were conducted in the period from mid to late August. The survey was addressed to Polish tourists who, after the lockdown and the restart of the tourist industry ${ }^{5}$, chose Polish cities as their holiday destination.

The questionnaire was supposed to reveal the behaviour of tourists during the pandemic, showing, among other things, whether urban tourism was an alternative to cancelled trips abroad, or whether it allowed seeing the advantages of domestic tourism.

The specification of the survey, due to the pandemic and the group of respondents to whom the questionnaire was addressed, did not make it easier to obtain a satisfactory number of questionnaires. As a result of the research, conducted between the $16^{\text {th }}$ and $31^{\text {st }}$ of August ${ }^{6}, 2020,559$ questionnaires were collected, with 456 taken into account for the final analysis of the results ${ }^{7}$.

\section{Urban tourism in the era of pandemic in Poland}

In the period from May to August, 2020, as a part of the urban tourism, the respondents visited a total of $232 \operatorname{cities}^{8}$ (Figure 1), i.e. almost 25\% of urban centres in Poland (these cities comprised more than 60 percent of the country's urban population.). Additionally, more than $70 \%$ of respondents indicated that they are planning further tourist trips to Polish cities by the end of 2020 .

Taking into consideration the number of tourists visiting, large cities (over 100 thousand residents) were the most popular destination. Most respondents chose Gdańsk (112

\footnotetext{
${ }^{5}$ In Poland, the period of the so called "defrosting of the economy" began on May 4, 2020, when hotels and other accommodation, as well as some tourist attractions were reopened. Since June 13, border traffic within the internal borders of the European Union has been restored.

${ }^{6}$ Due to the ongoing pandemic, the survey was conducted remotely using a google questionnaire sheet. The prepared form has been made available on facebook social network, more precisely on a private account, groups dedicated to tourism and the Linkedin website.

${ }^{7}$ In the analysis of the results (except for the elements from Figure 1 and Table 1) 103 surveys were not included, due to the fact that respondents in their questionnaire forms, apart from cities, also indicated villages as tourist destinations, which was contrary to the test assumptions.

${ }^{8}$ When presenting the results involving cities indicated and visited by the respondents, it was decided to include also those questionnaires in which the participants pointed several cities and villages they visited. In those cases, only the cities were taken into account from their answers. As a result, the analyze of 543 questionnaires was presented.
} 
Table 1: Cities visited as part of urban tourism according to the size of the city center

\begin{tabular}{lcccccc}
\hline \multicolumn{1}{c}{ Number of tourists } & $\begin{array}{c}\text { Number } \\
\text { of cities }\end{array}$ & $0-4$ & $5-24$ & $25-49$ & $50-99$ & $100-120$ \\
\hline $\begin{array}{c}\text { Large cities } \\
\quad<100 \text { thousand residents })\end{array}$ & 34 & 11 & 15 & 2 & 5 & 1 \\
$\begin{array}{c}\text { Medium cities } \\
\quad(20-100 \text { thousand residents })\end{array}$ & 79 & 61 & 15 & 1 & 2 & 0 \\
$\begin{array}{l}\text { Small towns } \\
\quad>20 \text { thousand residents })\end{array}$ & 119 & 101 & 18 & 0 & 0 & 0 \\
Total & 232 & 173 & 48 & 3 & 7 & 1 \\
\hline
\end{tabular}

Source: Own study based on surveys, $n=543$.

respondents), Kraków, Wrocław and Poznań (more than 80 respondents) as their holiday destinations (Table 1). The smallest number of people decided to opt for urban tourism in small towns (cities with population below 20 thousand) residents) - 71 small towns in Poland were visited by one respondent.

Although the largest urban centres in Poland were more attractive to the respondents, small and medium-sized centres dominated in the general structure of cities indicated by the respondents. This is due to the fact that a significant part of small towns is located in areas with high environmental values (in the vicinity of seas, mountains, forests, lakes), which strengthens their interest among tourists. On the other hand, small and mediumsized cities, located in the vicinity of bigger ones could complement tourist trips to the largest cities (as can be seen in the case of the city of Poznań, which belongs to large urban centres, and small towns located in its surroundings) (see Figure 1).

The respondents differed significantly when it comes to the list of indicated cities and later, when that number was summed up. As a result, it was observed that nearly $40 \%$ of the respondents visited only one city, while less than half of that visited two cities. Their choices included the largest urban centres (among others Warszawa, Kraków, Wrocław, Poznań). Tourists who visited more than three cities opted for the directions of urban tourism destinations concentrated in the area of a certain region (primarily located in the northern Poland, coastal cities: Gdańsk, Gdynia, Sopot, Hel, Łeba, Kołobrzeg, Ustroń, Ustka, Mielno). Among the respondents some people declared that during the pandemic they visited seven or even more cities (2 people indicated that they visited 10 cities, 1 person - 11 cities, 1 person - 13 cities). In this group, there were no certain choices among the cities given by tourists which would indicate one specific tourist region. This may result from the adopted form of recreation, focusing on touring urban tourism in previously selected Polish cities.

Urban tourism trips during the pandemic were associated with longer periods. Nearly half of the trips lasted 4 days and more (Figure 2). At that time, the respondents most often pointed to numerous seaside towns and much less frequently to urban centres located in the southern part of Poland. Before the pandemic, tourists used an average of 2.5 nights in cities in 2019. It can be concluded that the trend of those surveyed during the pandemic was close to similar to the nationwide statistics before Covid-19 (Główny Urząd Statystyczny 2020a).

In the case of one-day trips, the choice of cities was clearly linked to the place of residence. The respondents decided to opt for urban tourism in the area of the same or neighbouring province (see Table A.1). Decisions on the length of trips are justified, among others, by the indicated factors of the place (Figure 3) which determined the direction of the tourist destination. Nearly $22 \%$ of the respondents indicated that the short arrival time to the destination was an important factor in choosing the direction of the trip.

However, it is tourist attractions that have become the most relevant decision factor for the largest number of respondents. Issues related to the pandemic, namely the possibility to distance oneself in cities $(10,85 \%)$, or the information placed on websites 


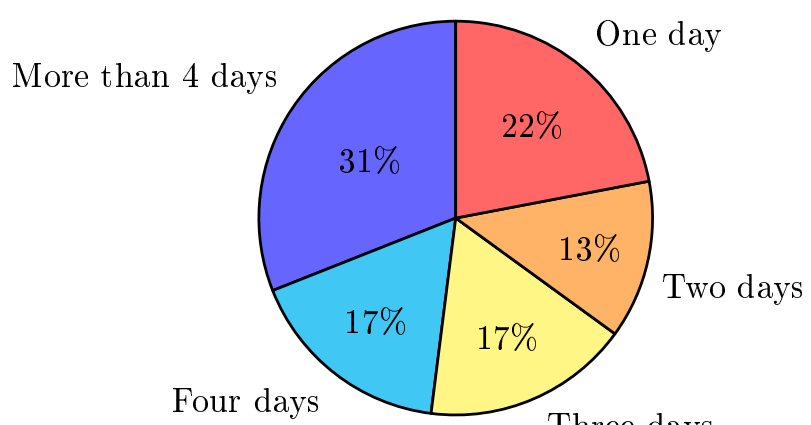

Source: Own study based on surveys, $n=456$.

Figure 2: Length of the holiday trips as a part of urban tourism

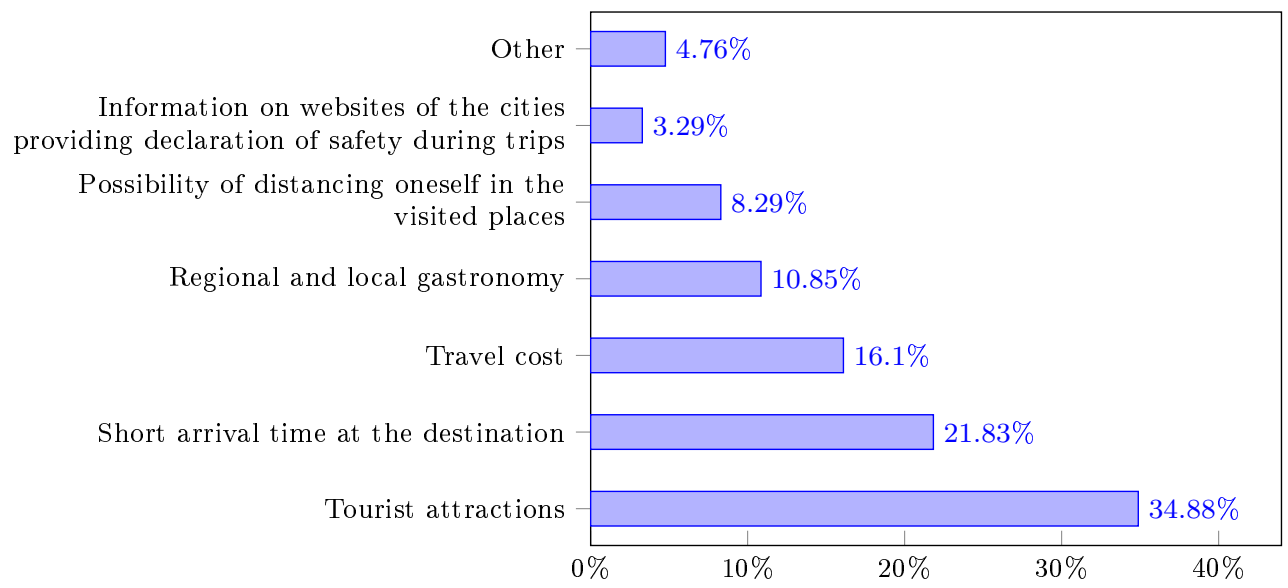

Source: Own study based on surveys, $n=456$.

Figure 3: Factors influencing the choice of the city as a tourist destination

with the declaration of safety guarantee during the departure $(3,29 \%)$, did not have such a significant impact on the decision made. Nearly $5 \%$ of the respondents also indicated other factors: slightly more than $4 \%$ of people related their decision to private issues, namely meeting family, relatives or friends, who live in or near the chosen city, $0,4 \%$ (3 people) of the respondents chose a given city because of the sporting events in which they participated, $0,2 \%$ ( 2 people) of the tourists considered attachment and certain family traditions as a factor, as these cities are places of regular, annual holiday trips.

In May, after the restrictions were partially lifted, $8 \%$ of respondents decided to go on holiday. However, almost $50 \%$ of this group consisted of people from single and double households. In the following month the number of respondents who decided to travel to Polish cities tripled. The peak of holiday trips fell in July and August, when $70 \%$ of the participants chose domestic urban tourism as their destination. Thus, it can be concluded that the pandemic did not change the behaviour of tourists as to the date of tourist travel. This is also confirmed by the previously indicated fact that over $70 \%$ of the respondents were not afraid of being infected with coronavirus during their travels. However, even in cases when people declared themselves afraid of the possibility of infection during the trip, in the end, visited on average as many cities as those who did not feel any fear.

More than $80 \%$ of respondents chose cities as their holiday trips, while for the rest, urban tourism was a complement to rural tourism. It would seem that, during the travels targeted at rural areas, the respondents would decide to complement their visits with smaller, less popular tourist destinations. However, the opposite happened, the list was dominated by the most attractive Polish cities such as Zakopane, Wrocław, Kraków and Gdańsk. 


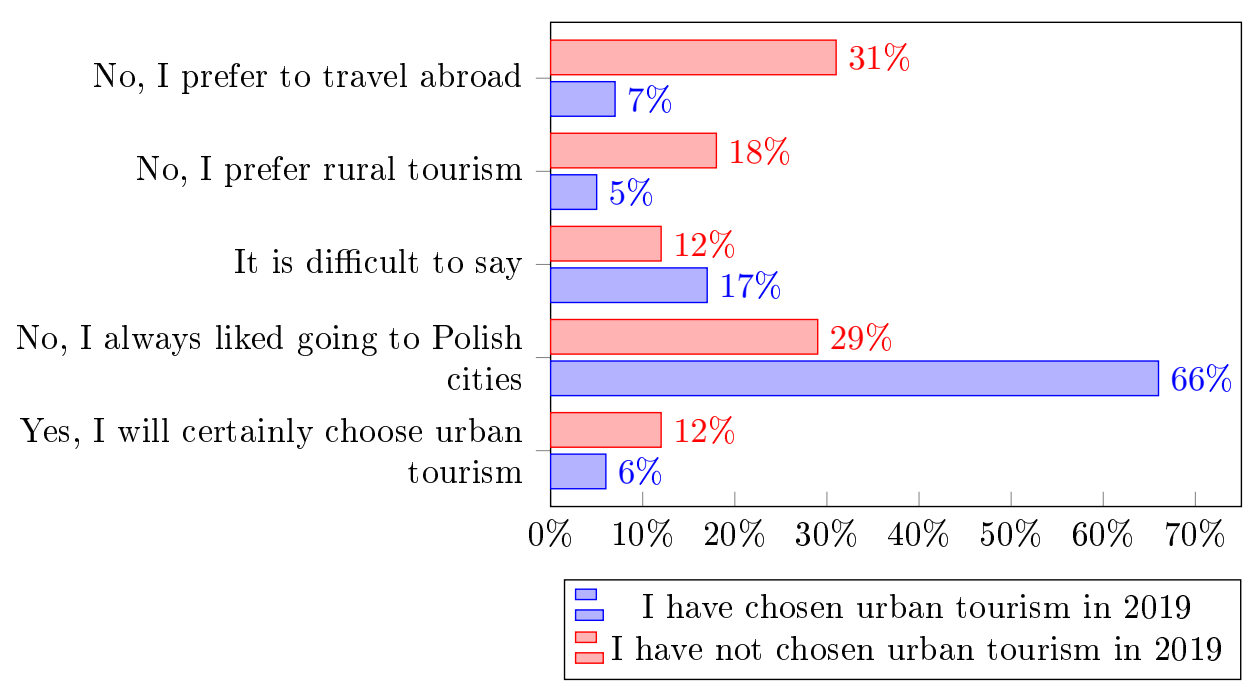

Source: Own study based on surveys, $n=456$.

Figure 4: Preferences after a tourist trip during a pandemic

Urban tourism was not a new destination during the pandemic. Almost $90 \%$ of the respondents indicated that a year prior, they also used the tourist attractions offered by Polish city centres. For $70 \%$ of the participants, cities visited in the period from May to August were urban centres that they had already visited before (the indicated places were the most popular tourist cities in Poland, including Zakopane, Gdańsk, Gdynia, Mielno, Kraków, or Wrocław. $24 \%$ of the respondents stated that not in all cases it was a re-visit in these cases, among the indicated, well-known cities were medium and small places (e.g. Bydgoszcz, Opole, Zamość, Toruń, Kudowa Zdrój, Supraśl, Ciechanowiec, and Drawsko Pomorskie). Only $16 \%$ of the participants visited the given cities for the first time, while almost half of the declared cities consisted of large urban centres. However, these choices may be due to the young age of the respondents who gave such an answer (18-35 years). Their choice was then focused on the most popular tourist cities.

Tourist preferences of the respondents after their trip varied, depending on whether they also benefited from urban tourism in the previous year. The surveyed tourists, who visited Polish cities in 2019, also took advantage of urban tourism during the coronavirus, due to the fact that they always preferred to go to urban centres in the country (66\%). Only $6 \%$ declared a greater inclination for urban tourism in the future. However, this should be justified by the fact that this group of respondents clearly indicated that they willingly choose cities as their destination. Therefore, the opinions of people who did not opt for urban tourism a year prior can be positively assessed - such an answer was given by $12 \%$ of respondents.

On the other hand, $31 \%$ of people (28 respondents), who did not choose urban tourism a year before, despite the fact that during the pandemic they decided on the trip, still prefer to go abroad more (Figure 4), supporting it with a fact that 15 of them travelled abroad in 2019, while 7 of them have also taken part in a trip outgoing since June 2020. This group is therefore made up of people who, with a certain degree of regularity, decide on resting places located outside the country. If we focus on the respondents in a general way, less than $60 \%$ of Polish tourists in the previous year took advantage of outgoing tourism. Moreover, during the pandemic, since June 2020, 20\% of them have used the opportunity to go to another country as a holiday destination. More than $4 \%$ of the respondents who did not choose outgoing tourism in 2019, did so in 2020, during the COVID-19 pandemic. The interest in foreign trips among Poles decreased by half due to the coronavirus. As a result, for $32 \%$ of the respondents, urban tourism was compensation for the planned outgoing tourism in the holiday period.

Although more than $70 \%$ of the participants were not afraid of the coronavirus infection, they rate the level of safety relatively low $-60 \%$ of the tourists who took 


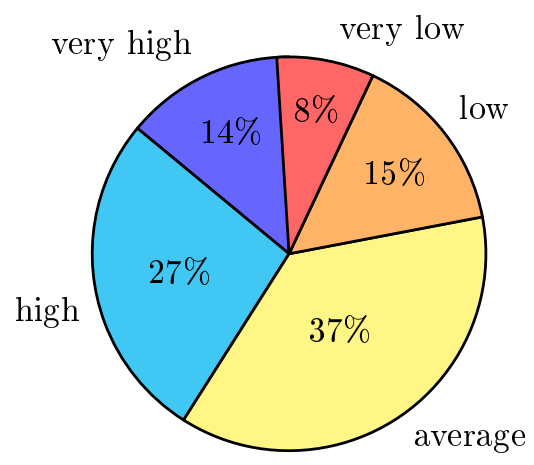

Source: Own study based on surveys, $n=456$.

Figure 5: Assessment of the safety level in cities during coronavirus threat

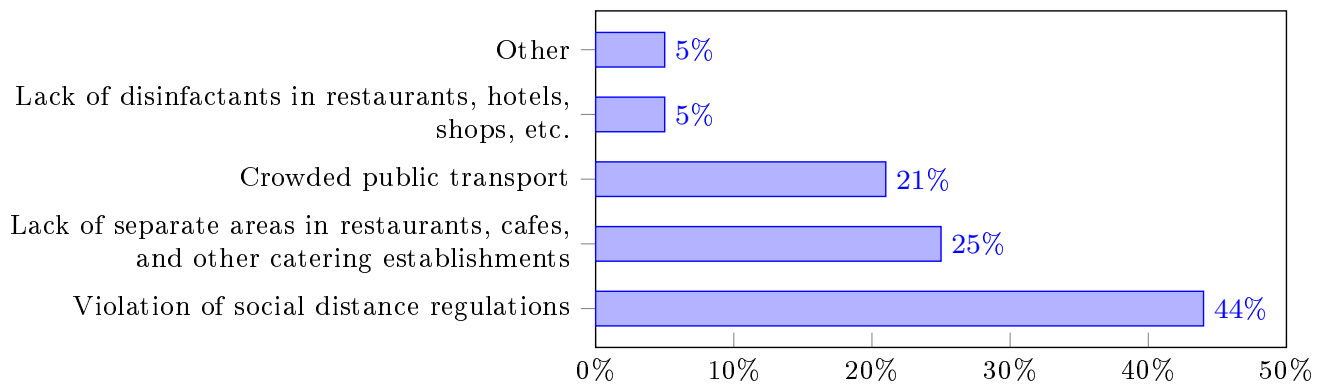

Source: Own study based on surveys, $n=195$.

Figure 6: Reasons for negative assessment of urban safety levels

part in the study gave an unfavourable (very bad, bad or average) assessment of the said level in cities (Figure 5).

In this group, the most frequently indicated reason for the negative assessment of the level of security in cities (Figure 6) was a violation of the principles of social distance ( $44 \%$ of the respondents), $25 \%$ emphasized the lack of separate places in catering establishments.

Among other reasons given (5\%), there were repeated opinions about the lack of mask coverage in places, where such a rule applied for both other tourists and staff in cafes or restaurants. The respondents pointed out negative aspects, lying both on the side of tourists and facilities or staff. Thus, one can speak of a certain underestimation of the rules, even though there were financial penalties for breaking them.

During their trips, the respondents travelled mainly by their own or rented (borrowed) car (64\% of the participants), $23 \%$ opted for rail transport, while $10 \%$ opted for bus transport. Only $1 \%$ of tourists reached the city by plane. However, such a small group results from the fact that air transport is not very popular in the country and that the airports are located only in a few cities in Poland. Among the respondents, there were also people (3 participants), who only travelled by bicycle during their trip, which suggests the form of tourist travel around the cities they chose.

In connection with the introduction of the Polish tool to revive the tourism industry during the pandemic in the form of a tourist voucher, the respondents were asked whether they took advantage of such an opportunity. It was used by $2 \%$ of the respondents. However, a small percentage is due to the low number of households participating in the survey that could have used this type of tool (see Table A.1).

The survey and analysis of its results made it possible to present the tourists' suggested behaviours during the pandemic. The research has allowed us to observe that the general directions or actions taken before and during the trip do not differ significantly from those before the coronavirus outbreak, which are presented in public statistics (see the 
publications of Główny Urząd Statystyczny at https://stat.gov.pl/). The destinations of the largest number of tourists were large urban centres, even though they confirm a higher number of infections.

\section{Discussion}

Tourism in the nineteenth century is beginning to be considered as one of the basic human needs (Sala 2012), becoming, to some extent, a necessity of society (Wachyuni, Kusumaningrum 2020). The coronavirus pandemic has stopped the tourism sector (Wojcieszak-Zbierska et al. 2020), but also the society from the realization of its needs. The global blockade has shown people a new face of, among others, tourism, forcing them to, on the one hand, adapt to the current situation, and on the other, to create new solutions and search for potentials where they had not been noticed before.

As we know, it is difficult to estimate the effects of the crisis, which is not yet over. However, one can find positive aspects in it. One of them was indicated as a part of the conducted research. The potential for the Polish tourism sector is, among others, urban tourism. Cities, being attractive destinations, did not lose their relevance during the pandemic in Poland. Although the number of infected cases in cities is much higher than in rural areas, urban centres are a popular tourist destination.

The tourism industry will certainly recover from the coronavirus crisis. However, the question arises, whether it will look the same as before the pandemic. The economic revival, after the partial lifting of restrictions, may result in the formation of new patterns of holiday trips, more focused on domestic tourism among visitors.

Therefore, the representatives of the tourism industry are currently faced with a considerable challenge, as they have to carry out their tourism activities during the pandemic, and, at the same time, analyse tourists' behaviour, their requirements, expectations and preferences. According to Andreini, Mangiò (2020), the tourism sector should acquire new services to provide to tourists that focus on increasing self-esteem, meeting the needs of the higher-order and not on available promotions and discounts. This form of tourism is visible in experienced visitors, which argues for the validity of such services.

The research showed that the tourists were mostly targeting large cities during the pandemic. In individual cases, small urban centres were indicated. This is, in a way, due to the fact that the largest cities in Poland are the main tourist destinations for Poles, but also for foreign tourists, because of their advantages, which are mostly concentrated in large urban centres (Preisler 2012). Small urban centres differ significantly, when the variety of tourist attractions is concerned, with the exception of cities with high environmental values (cities located near the sea, lakes, or mountains).

Polish tourists, who took part in the survey, were not afraid of coronavirus infection during their trips. This may stem from the fact that: the group of the respondents was made up of people who rather systematically benefit from tourism, not only in Poland, but also abroad, a significant proportion of subjects were young adults who were less frequently exposed to Covid-19 and, to some extent, from the place of obtaining respondents $^{9}$. This is also due to specific characteristics of urban tourism such as the shortness of stays or the repetitiveness of visits, among others (Lerario, Di Turi 2018, Ashworth, Page 2011, Dumbrovská, Fialová 2014).

The lack of fear of infection was also noticeable in the indicated factors determining the choice of a tourist destination (the possibility of social distancing was a factor taken into account by a little more than $10 \%$ of the respondents). Despite the lack of concern, the chosen cities were negatively assessed in terms of safety and did not discourage further trips as a part of urban tourism.

The results of the questionnaire indicated that Poles like to use domestic urban tourism ( $60 \%$ of the participants). Moreover, less than $10 \%$ of the tourists have decided that, in the future, after this year's trips, they will use the tourist attractions of Polish

\footnotetext{
${ }^{9}$ Travel and tourism groups on social networking sites are created by people who regularly travel, run blogs, websites, but also by family travel enthusiasts. In the created thematic groups, they regularly exchange information, recommending specific places, hence the established tourism trends among the respondents, despite the ongoing pandemic.
} 
cities more often. The pandemic has therefore influenced, to some extent, the perception of national urban tourism. It is also interesting to note that the directions of the destinations were, in many cases, the cities visited in previous years, which proves a certain attachment to the holiday destination and guarantee of safety during the pandemic. The results of the surveys of people who chose several cities, and then reported that not all of them have been visited before, indicate that in the group of these urban centres there is a dominant majority of medium and small towns. Therefore, one can come to the conclusion that, due to the coronavirus, a group of respondents decided to visit less touristic cities, thus increasing the possibility of social distancing.

To sum up, the results of the research showed that the behaviour and decisions of tourists do not differ from those before the pandemic. This has its positive and negative consequences. On the list of the disadvantages is the issue of the rising number of cases of coronavirus transmission caused by increased mobility. The positive aspect of the respondents' behaviour can be considered as an advantage for the national tourism industry. Despite the pandemic, people have not changed their behaviour, they have limited it to some extent. Thus, if in the era of COVID-19, the society decides on a permanent form of vacationing, it will continue to perpetuate this pattern even after its completion. Negative assessments of the safety levels are only a signal to cities and the tourism sector to increase the quality of care for tourists during the coronavirus because it seems to be one of the main shortcomings of the industry today.

\section{References}

Anand A, Kim DH (2021) Pandemic induced changes in economic activity around African protected areas captured through night-time light data. Remote Sensing 13: 314. CrossRef

Andreini D, Mangiò F (2020) Back to the basics in the tourism marketing during Covid19 emergency. In: Burini F (ed), Tourism facing a pandemic: From crisis to recovery. Università degli Studi di Bergamo, Bergano, Italy, 53-62

Ashworth G, Page S (2011) Urban tourism research: Recent progress and current paradoxes. Tourism Management 32: 1-15. CrossRef

Barrera-Fernandez D, Hernández-Escampa M, Vázquez A (2016) Tourism management in the historic city. The impact of urban planning policies. International Journal of Scientific Management and Tourism 2: 349-367

Dumbrovská V, Fialová D (2014) Tourist intensity in capital cities in central Europe: comparative analysis of tourism in Prague, Vienna and Budapest. Czech Journal of Tourism 1: 5-26. CrossRef

Fletcher R, Büscher B, Massarella K, Koot S (2020) Ecotourism and conservation under COVID-19 and beyond. ATLAS Tourism and Leisure Review 2020: 42-50

Główny Urząd Statystyczny (2020a) Turystyka w 2019r. [Tourism in 2019]. Warsaw, Rzeszów: Główny Urząd Statystyczny

Główny Urząd Statystyczny (2020b) Wykorzystanie turystycznej bazy noclegowej w Polsce w czerwcu i lipcu 2020 r. [Use of tourist accommodation in Poland in June and July 2020.]. Warsaw: Główny Urząd Statystyczny

Główny Urząd Statystyczny (2020c) Wykorzystanie turystycznej bazy noclegowej w Polsce w kwietniu i maju 2020 r. [Use of tourist accommodation in Poland in April and May 202.]. Warsaw: Główny Urząd Statystyczny

Grah B, Dimovski V, Peterlin J (2020) Managing sustainable urban tourism development: The case of Ljubljana. 12: 792. CrossRef

Gössling S, Scott D, Hall C (2020) Pandemics, tourism and global change: A rapid assessment of COVID-19. Journal of Sustainable Tourism: 1-20. CrossRef 
Jamal T, Budke C (2020) Tourism in a world with pandemics: Local-global responsibility and action. Journal of Tourism Futures 6: 181-188. CrossRef

Keller P (2020) Corona pandemic as exogenous shock for international tourism: A context analysis. In: Burini F (ed), Tourism facing a pandemic: From crisis to recovery. Università degli Studi di Bergamo, Bergano, Italy, 15-24

Komisja Europejska (2020) Komunikat Komisji do Parlamentu Europejskiego, Rady, Europejskiego Komitetu Ekonomiczno-Społecznego i Komitetu Regionów. Turystyka i transport w roku 2020 i w dalszej przyszłości[Communication from the Commission to the European Parliament, the Council, the European Economic and Social Committee and the Committee of the Regions. Tourism and transport in 2020 and beyond]. European Commission, Brussels

Królikowska-Tomczak A, Machnik A (2019) Zrównoważona turystyka miejska w kontekście turystyki kulturowej [Sustainable urban tourism in the context of cultural tourism]. Turystyka Kulturowa 5: 76-98

Kyrylov Y, Hranovska V, Boiko V, Kwilinski A, Boiko L (2020) International tourism development in the context of increasing globalization risks: on the example of Ukraine's integration into the global tourism industry. Journal of Risk and Financial Management 13: 303. CrossRef

Labonte R, Mohindra K, Schrecker T (2011) The growing impact of globalization for health and public health practice. Annual Review of Public Health 32: 263-283. CrossRef

Lama R, Rai A (2021) Challenges in developing sustainable tourism post COVID-19 pandemic. In: Gowreesunkar V, Maingi S, Roy H, Micera R (eds), Tourism Destination Management in a Post-Pandemic Context. Emerald Publishing Limited, Bingley, 233244. CrossRef

Lerario A, Di Turi S (2018) Sustainable urban tourism: Reflections on the need for building-related indicators. Sustainability 10: 1981. CrossRef

Napierała T, Leśniewska-Napierała K, Burski R (2020) Impact of geographic distribution of COVID-19 cases on hotels' performances: Case of Polish cities. Sustainability 12: 4697. CrossRef

Orîndaru A, Popescu M, Alexoaei A, Căescu S, Florescu M, Orzan A (2021) Tourism in a post-COVID-19 era: Sustainable strategies for industry's recovery. Sustainability 13: 6781. CrossRef

Polish Tourist Organisation (2020) Plany Wakacyjne Polaków 2020. [Poles' 2020 holiday plans]. https://www.pot.gov.pl/attachments/article/1804/Plany wakacyjne Polaków 2020 ost..pdf (14.09.2020)

Polukhina A, Sheresheva M, Efremova M, Suranova O, Agalakova O, Antonov-Ovseenko A (2021) The concept of sustainable rural tourism development in the face of COVID19 crisis: Evidence from Russia. Journal of Risk and Financial Management 14: 38. CrossRef

Popescu R, Corbos R (2010) The role of urban tourism in the strategical development of Brasov area. Theoretical and Empirical Researches in Urban Management 16: 69-85

Preisler M (2012) Uwarunkowania atrakcyjności turystycznej miasta. [Determinants of tourist attractiveness of the city]. Studia Periegetica 8: 133-153

Purcell W, Burns M, S O, Voss A (2021) COVID-19 and sustainable tourism. In: Leal Filho W (ed), COVID-19: Paving the Way for a More Sustainable World, World Sustainability Series. Springer, Cham, 163-184. CrossRef 
Richards G (2020) The impact of crisis on travel: Covid-19 and other shocks. In: Burini F (ed), Tourism facing a pandemic: From crisis to recovery. Università degli Studi di Bergamo, Bergano, Italy, 25-31

Richards G, Morrill W (2020) The impact and future implications of COVID-19 in the youth travel sector. ATLAS Review 2: 57-64

Rodríguez-Anton J, del Mar Alonso-Almeida M (2020) COVID-19 impacts and recovery strategies: The case of the hospitality industry in Spain. Sustainability 12: 8599. CrossRef

Roman M, Niedziółka A, Krasnodębski A (2020) Respondents' involvement in tourist activities at the time of the COVID-19 pandemic. Sustainability 12: 9610. CrossRef

Sala J (2012) Miasta jako cel podróży turystycznych w Polsce [Cities as tourist destinations in Poland]. Studia Ekonomiczne. Zeszyty Naukowe Wydziałowe Uniwersytetu Ekonomicznego w Katowicach (Turystyka na obszarach miejskich. Uwarunkowania rozwoju. Narzędzia promocji): 20-32

Szołtysek J, Otręba R (2020) Attractiveness of cities during social isolation: Views of residents of the Silesian Voivodeship (Poland). Ekonomika regiona 16: 1272-1284. CrossRef

UN Habitat (2020) UN-Habitat COVID-19 response plan. Nairobi: UN Habitat

Vărzaru A, Bocean A, G C, Cazacu M (2021) Rethinking tourism industry in pandemic COVID-19 period. Sustainability 13: 6956). CrossRef

Wachyuni S, Kusumaningrum A (2020) The effect of COVID-19 pandemic: How are the future tourist behavior? Journal of Education, Society and Behavioural Science 33: 4. CrossRef

Więckowski M (2021) Will the consequences of Covid-19 trigger a redefining of the role of transport in the development of sustainable tourism? Sustainability 13: 1887. CrossRef

Więckowski M, Saarinen J (2019) Tourism transitions, changes, and the creation of new spaces and places in Central-Eastern Europe. Geographia Polonica 92: 369-377. CrossRef

Wojcieszak-Zbierska M, Jęczmyk A, Zawadka J, Uglis J (2020) Agritourism in the era of the coronavirus (COVID-19): A rapid assessment from Poland. Technical Report 9. CrossRef

World Tourism Organization (2020) UNWTO briefing note - Tourism and COVID-19, issue 1 - how are countries supporting tourism. Madrid: UNWTO. CrossRef

WYSE Travel Confederation (2020) COVID-19 business travel impact survey. Amsterdam: WYSE travel confederation

Yang Y, Zhang H, Chen X (2020) Coronavirus pandemic and tourism: Dynamic stochastic general equilibrium modeling of infectious disease outbreak. Annals of Tourism Research 83. CrossRef

Żabińska T (2013) Turystyka w dużych miastach i metropoliach. Wybrane problemy rozwoju i zarządzania [Tourism in large cities and metropolises. Selected problems of development and management]. Studia Ekonomiczne (147 Turystyka miejska. Prawidłowości $i$ determinanty rozwoju): 133-153 


\section{A Appendix:}

Table A.1: Metrics

\begin{tabular}{llc}
\hline Specification & Female & $\begin{array}{c}\text { Percentage of } \\
\text { respondents }\end{array}$ \\
\hline Sex & Male & $82 \%$ \\
Age & 18-24 years old & $18 \%$ \\
& $25-34$ years old & $36 \%$ \\
& $35-44$ years old & $31 \%$ \\
& $45-54$ years old & $22 \%$ \\
Place of residence & Over 55 years old & $8 \%$ \\
& countryside & $2 \%$ \\
& small town & $24 \%$ \\
Number of & average town & $10 \%$ \\
household's & big city & $15 \%$ \\
members & single & $50 \%$ \\
& 2-person & $11 \%$ \\
Region & 3-person & $30 \%$ \\
(macroregion) & 4-person & $23 \%$ \\
& over 4 people & $25 \%$ \\
& Northern & $11 \%$ \\
& Mazowieckie voivodship & $10 \%$ \\
& Eastern & $9 \%$ \\
& Central & $6 \%$ \\
& Southern & $8 \%$ \\
& South-Western & $14 \%$ \\
& North-Western & $8 \%$ \\
& & $45 \%$ \\
\hline
\end{tabular}

Note: "small town" - up to 20 thousand residents; "average town" - between 20 and 100 thousand residents; "big city" - over 100 thousand residents

cc () () () () 2021 by the authors. Licensee: REGION - The Journal of ERSA, European

Regional Science Association, Louvain-la-Neuve, Belgium. This article is distri-

buted under the terms and conditions of the Creative Commons Attribution, Non-Commercial (CC BY NC) license (http://creativecommons.org/licenses/by-nc/4.0/). 